\title{
A School Effectiveness Approach to Good Citizenship
}

\author{
Ernesto Treviño, Diego Carrasco, Natalia López Hornickel, \\ and Carmen Gloria Zúñiga
}

\begin{abstract}
Schools are traditionally considered agents of political socialization. However, the school's capacity to promote citizenry among students is often considered limited, in comparison to the expected influence of the socioeconomic background of students' families. Using data from IEA's International Civic and Citizenship Education Study (ICCS), this chapter inquires if schools' differences are related to students' citizenship norms endorsement, focusing on the relationship between civic learning opportunities and open classroom discussion of schools on promoting citizenship norms endorsement among students. To this end, a multilevel multinomial base category logit model is used, including students' and schools' characteristics specifying citizenship norms profiles as the dependent variable. Citizenship norms profiles is a nominal variable, that summarize the way students endorse 12 different citizenship norms, across countries. Results suggest that schools explain a non-ignorable portion of the variance of students' citizenship norms endorsement. Additionally, civic learning opportunities and open classroom discussion are school practices that promote a comprehensive endorsement of citizenship norms, above students' socioeconomic background, and students' civic background across countries. Implications for civic education are discussed.
\end{abstract}

Keywords Citizenship norms • Duty-based citizenship • Engaged citizenship • School practices $\cdot$ International Civic and Citizenship Education Study (ICCS)

\author{
E. Treviño $(\bowtie)$ \\ Facultad de Educación and Centro de Justicia Educacional, Pontificia Universidad Católica de \\ Chile, Santiago, Chile \\ e-mail: ernesto.trevino@uc.cl \\ D. Carrasco \\ Centro de Medición MIDE UC, Pontificia Universidad Católica de Chile, Santiago, Chile \\ e-mail: dacarras@uc.cl
}

N. López Hornickel · C. G. Zúñiga

Facultad de Educación, Pontificia Universidad Católica de Chile, Santiago, Chile e-mail: nvlopez@uc.cl

C. G. Zúñiga

e-mail: carmen.zuniga@uc.cl

(C) International Association for the Evaluation of Educational Achievement (IEA) 2021

E. Treviño et al. (eds.), Good Citizenship for the Next Generation,

International Association for the Evaluation of Educational Achievement (IEA)

Research for Education 12, https://doi.org/10.1007/978-3-030-75746-5_5 


\section{Introduction}

Schools are at the crux of the political socialization process. Specifically, this process refers to the way in which political norms and desirable behaviors for a political system are transmitted between generations (Sigel 1965). The role of the school is to provide learning opportunities that implement civic formation for all students because political norms are not equally distributed across all adults. In consequence, the intergenerational transmission hypothesis posits that existing political inequities among adults are inherited from parents to children (Schlozman et al. 2012). Previous research on citizenship norms is consistent with this expectation: citizenship norms endorsement is conditioned by the educational attainment of adults (Coffé and van der Lippe 2010; Denters et al. 2007; Reichert 2017). As such, without any intermediate action, there is no guarantee that political norms and desirable behaviors will be transmitted from families to their offspring without fault. In this scenario, schools have a compensatory role in enhancing the lack of political socialization occurring at home (Hoskins et al. 2017). However, there is a gap in the citizenship norms literature regarding the capacity of schools to influence citizenship norms endorsement, and if any, what schools' practices drive this influence.

The importance of schools in promoting citizenship skills and knowledge in order to create more cohesive societies is a common notion in education policy debates (Heyneman 2000; Jansen et al. 2006). However, available evidence shows that schools have a limited capacity to enhance citizenship skills and attitudes among students (Bickmore 2001; Weinberg and Flinders 2018; Westheimer and Kahne 2004b).

The present chapter assesses two questions: if school membership is related to citizenship norms endorsement, and if civic education school practices are related to students' citizenship endorsement. To this end, we use a manifest nominal variable that summarizes how grade 8 students endorse different citizenships norms. Citizenship norms endorsement is not easily represented by a single continuum and alternatively can be represented as types or configurations (Hooghe and Oser 2015; Hooghe et al. 2016). The present chapter makes use of this later typology, where a set of 12 different citizenship norms are summarized into five different response patterns, including: comprehensive, socially engaged, duty-based, monitorial, and anomic. These different types represent the most likely way that students would endorse different citizenship norms (see Chap. 3). In essence in the present chapter, we inquire if school promotes citizenship norms endorsement by comparing which citizenship norms types are more likely, conditional to school membership, and conditional to different schools' practices and attributes. 


\section{Literature Review}

To what extent different institutions foster citizenship development is an open question. Family background characteristics influence different positive aspects of citizenship (Treviño et al. 2018, 2019). School factors, such as student participation in schools and open classroom discussion, have been linked to students' expected participation in the political system (Isac et al. 2014; Treviño et al. 2019) and to the endorsement of egalitarian attitudes towards minority groups (Carrasco and Torres Irribarra 2018; Treviño et al. 2018).

The socioeconomic status (SES) of students' families is an important predictor of civic knowledge, skills, and dispositions (Castillo et al. 2014; Hooghe and Dassonneville 2013; Isac et al. 2014; Schulz et al. 2010; Thapa et al. 2013). Student SES may have both direct and indirect effects. The first, refers to differences among students due to the socioeconomic background of the families where the students grew up. The second, refers to the differing learning opportunities students are exposed to at their schools (Collado et al. 2014; Isac et al. 2014). Consequently, we expect that students' SES is associated to the citizenship norms endorsement of the students.

Student characteristics relevant to understand students' citizenship norms are not limited to their family socioeconomic background. There are additional aspects of the civic background of students we need to consider before school comparisons can be made. Civic background includes student characteristics such as political interest, opportunities for political discussion outside their schools, and engagement with political news media. These different factors are thought to be heavily influenced by the family environment (Patterson et al. 2019; Treviño et al. 2019), and are related to different forms of citizenship participation (Campbell 2008; Treviño et al. 2019). These characteristics are unequally distributed among students and families, a phenomenon which translates into political participation inequalities later in life (Schlozman et al. 2012; Verba et al. 1995, 2003). Thus, given the previous literature we assume that these different civic background characteristics may condition what citizenship norms students endorse the most.

As we mentioned earlier, schools with a higher SES composition tend to present better civic outcomes in comparison to other schools, including civic knowledge and other non-cognitive outcomes (Collado et al. 2014; Isac et al. 2014). However, the literature of school effectiveness suggests these differences are explained by other attributes of the school environment that includes features of school processes (e.g., Liu et al. 2015). Within the civic education literature, there are known teaching strategies that influence both students' attitudinal and participation outcomes (Dassonneville et al. 2012; Quintelier 2010; Reimers et al. 2014). For example, open classroom discussion is related to voting intention (Campbell 2008), civic knowledge (Persson 2015), endorsement of egalitarian values (Caro and Schulz 2012; Carrasco and Torres Irribarra 2018), students' political efficacy (Martens and Gainous 2013), and civic competences in general (Isac et al. 2014; Knowles et al. 2018). Additionally, formal civic learning oportunities at school are also related to different citizenship outcomes, including intended political participation (Reichert and Print 2018), 
actual political participation (Quintelier 2010), and commitment to civic participation (Kahne and Sporte 2008). We hypothesize that the exposure to civic learning oportunities at school should have a significant relationship with the students' citizenship norms endorsement.

Besides school practices, characteristics of the school climate are expected to have positive relationships with different student citizenship outcomes (Sampermans et al. 2018). A participatory and democratic environment in the school is related to attitudes and dispositions of youth towards democracy and civic engagement (Biesta et al. 2009; Wilkenfeld 2009), as well as expected voting and civic knowledge (Schulz et al. 2010; Thapa et al. 2013). In summary, participatory schools, and schools with better interpersonal relationships between students and teachers, are expected to provide more nurturing environments for citizenship development. As a consequence, we expect these school features to be associated to students' citizenship norms endorsement.

The available evidence shows that different student and school characteristics are related to different citizenship outcomes. In the present study we inquire how these different factors are related to students' citizenship norms endorsement. In particular we are interested in the relationship between different school attributes and what citizenship norms students endorse the most, independent of the students' attributes. It is expected that different schools may shape different citizens (Kahne et al. 2013; Westheimer and Kahne 2004a, b). Are schools promoting more duty-based students? These students are obedient to the law and respect authorities, and willing to vote, but less interested in politics. Are schools promoting socially-engaged students? This group of students defend civil rights, participate in the local community, are willing to vote but are less inclined to engage with political parties or discuss politics. Or are schools promoting more comprehensive students? Those who are willing to defend human rights and protest against unjust laws, while simultaneously engaging in political discussion and voting in national elections. These are relevant questions for civic education, because the endorsement of citizenship norms puts pressure on people to guide their behavior (Legros and Cislaghi 2019). Especially when these are injunctive citizenship norms, which express what is expected and what is sanctioned (Cialdini and Goldstein 2004). Citizenship norms studied here are different norms relevant to support democratic procedures including compliance to the law, voting in elections, and social engagement with the community (van Deth 2017).

Finally, this chapter uses the citizenship norms endorsement profiles presented in Chap. 3 as an outcome variable. This is a nominal variable that expresses what citizenship norms students endorse the most, generated with a mixture model, producing different equivalent latent classes across countries. In the present chapter we use the latent realizations of the model as manifest variables. This nominal variable consists of five different profiles: comprehensive, anomic, monitorial, socially engaged, and duty-based. These groups are described in the next section. 


\section{Method}

Data. We use secondary data from the International Civic and Citizenship Education Study (ICCS) 2016 (Schulz et al. 2018a), conducted by the International Association for the Evaluation of Educational Achievement (IEA). This study uses a two-stage sampling design, where random schools are selected at the country level using a probabilistic stratified design. From these schools, a classroom is selected, and all students answered different instruments, conforming to a representative sample of grade 8 students for each participating country. In the present chapter, we include data from 24 countries and regions, accounting for a total of 93,246 students and 3750 schools. On average, 3885 students and 156 schools per country participate in the study (Schulz et al. 2018b). All our selected variables present less than 5\% missing $($ mean $=2 \%$, standard deviation $=1 \%)$.

Dependent variable. The endorsement of citizenship norms is a nominal variable that represents how students endorse 12 different citizenship norms. These were generated using a homogenous multigroup latent class model (Kankaraš and Vermunt 2015; Masyn 2017), producing different equivalent latent classes across countries (see Chap. 3). These are five values, distinguishing the most likely response pattern to the selected citizenship norms. Students can be (a) comprehensive, (b) socially engaged, (c) duty-based, (d) monitorial, and (e) anomic regarding their citizenship norms endorsement.

Students of the "comprehensive" profile are students who express that all civic norms are important to them. "Anomic" students disregard all selected citizenship norms simultaneously, showing the least endorsement in comparison to the rest of the profiles. "Monitorial" students tend to value non-conventional forms of political participation, while disregarding to join political parties and engaging in political discussions. "Socially engaged" students show high endorsement for citizenship norms for the protection of the environment and the promotion of human rights, and value the participation in activities that benefit the local community, as well as the obedience of the law and respect for government representatives. However, sociallyengaged students are less likely to consider participation in political discussions and joining a political party important. Finally, "duty-based" are students who considered obedience of the law, working hard, and voting in every election important, while disregarding the importance of participating in peaceful protests, engaging in political discussions, as well as joining a political party and participating in activities for the community. In summary these profiles express how students endorse citizenship norms (Hooghe and Oser 2015; Hooghe et al. 2016).

Independent variables. In the present study we include a series of student and school characteristics reported by the students. In the following tables we describe the variables included in the model, comprising student background characteristics and measures of the student's experience at their school (see Tables 1 and 2). This later group of measures includes variables that represent school processes related to civic learning and students' overall school experience (see Table 2). Although all 
Table 1 Student characteristics explaining citizenship norms endorsement profiles

\begin{tabular}{|c|c|}
\hline Variable & Variable name (type) and description \\
\hline $\operatorname{ses}_{i j}$ & $\begin{array}{l}\text { Student socioeconomic status (continuous). This is a standardized variable, with a } \\
\text { mean of } 0 \text {, and standard deviation of } 1 \text { for each country. Higher values indicate higher } \\
\text { socioeconomic status of students' families }\end{array}$ \\
\hline $\operatorname{sex}_{i j}$ & $\begin{array}{l}\text { Student sex (dummy). This variable is retrieved from the self-report of students' } \\
\text { sexual identity. Students respond if they were either girl or boy. Their responses were } \\
\text { dummy coded, assigning a } 1 \text { for girls, and a } 0 \text { for boys }\end{array}$ \\
\hline$i m m_{i j}$ & $\begin{array}{l}\text { Immigrant status (dummy). Students respond in what country their parents were } \\
\text { born. Students' responses were assigned a } 1 \text { if both parents were born abroad or if } \\
\text { students and parents were born in a different country from the study. Students were } \\
\text { classified as non-immigrant, receiving a } 0 \text {, if only one of their parents was born in the } \\
\text { surveyed country }\end{array}$ \\
\hline int $_{i j}$ & $\begin{array}{l}\text { Student interest in political and social issues (dummy). Students self-report their } \\
\text { interest in political and social issues using an ordinal response from very interested, } \\
\text { quite interested, not very interested and not interested at all. We dummy coded these } \\
\text { responses into } 1 \text { for "very interested" and "quite interested," and } 0 \text { for "not very } \\
\text { interested and not interested at all" to aid interpretation }\end{array}$ \\
\hline pol $_{i j}$ & $\begin{array}{l}\text { Student discussion of political and social issues outside school (IRT). Students } \\
\text { respond to four ordinal items on how frequently they talk to their parents and friends, } \\
\text { about political and social issues, and to what is happening in other countries. Higher } \\
\text { scores indicate more frequent political discussion }\end{array}$ \\
\hline$s o c_{i j}$ & $\begin{array}{l}\text { Student political social media use (IRT). Students respond to three ordinal items on } \\
\text { how frequently they use the internet to find information about political and social } \\
\text { issues, and post or comment political and social issues on the internet. Higher scores } \\
\text { indicate more frequent social media use with a political content }\end{array}$ \\
\hline par $_{i j}$ & $\begin{array}{l}\text { Student participation (IRT). Students respond to six items to express how frequently } \\
\text { they have participated in political activities within their school. These include voting } \\
\text { for a class representative, discuss in a student assembly, and become a candidate. } \\
\text { Higher scores indicate a higher level of student participation on these activities }\end{array}$ \\
\hline
\end{tabular}

Notes IRT refers to item response theory weighted least estimates scores. These are continuous measures with a mean of 50 and standard deviation of 10 points, for equally weighted countries (Schulz et al. 2018b)

Source ICCS 2016 user guide (Köhler et al. 2018)

these variables are collected at the student level, we use the students' aggregated scores at the school level to represent different school factors in the fitted model.

Specified model. We fit a baseline category logit model with random intercepts for schools (Rabe-Hesketh and Skrondal 2012). In this model we choose the comprehensive profile as the reference category. The student level model can be represented by the following equation (see Eq. 1).

$$
\begin{aligned}
\ln \left\{\frac{\operatorname{Pr}\left(c n_{i j}=s \mid x_{i j}, x_{. j}, r_{0 j}\right)}{\operatorname{Pr}\left(c n_{i j}=r \mid x_{i j}, x_{. j}, r_{0 j}\right)}\right\}= & \pi_{0 j}^{[s]}+\pi_{1 j}^{[s]}\left(\operatorname{ses}_{i j}-\overline{\operatorname{ses}}_{. j k}\right)+\pi_{2 j}^{[s]}\left(\operatorname{sex}_{i j}-\overline{\operatorname{sex}}_{. j k}\right) \\
& +\pi_{3 j}^{[s]}\left(i m m_{i j}-\overline{i m m}_{. j k}\right)+\pi_{4 j}^{[s]}\left(i n t_{i j}-\overline{i n t}_{. j k}\right)
\end{aligned}
$$


Table 2 Student responses that express their experience at school

\begin{tabular}{l|l}
\hline Variable & Variable name (type) and description \\
\hline opd $_{i j}$ & $\begin{array}{l}\text { Open classroom discussions (IRT). Students respond to six ordinal items referring to } \\
\text { how open for discussion their classroom is. These responses are used to generate IRT } \\
\text { scores. Higher scores indicate a more open classroom for discussion, where teachers } \\
\text { encourage students to express their opinions, make up their minds, and discuss issues } \\
\text { with others with different opinions }\end{array}$ \\
\hline $\operatorname{cln}_{i j}$ & $\begin{array}{l}\text { Civic learning (IRT). Students respond to seven ordinal items regarding to what extent } \\
\text { they have learnt about different civic topics. These include, for example, learning } \\
\text { about how to vote in local and national elections, how laws are introduced in their } \\
\text { country, and how citizens' rights are protected. Higher scores indicate higher exposure } \\
\text { to these different opportunities to learn }\end{array}$ \\
\hline$r e l_{i j}$ & $\begin{array}{l}\text { Teacher-student relations at school (IRT). Students respond to five ordinal items } \\
\text { referring to teacher-student relations. Higher scores indicate more positive } \\
\text { teacher-student relations, where teachers treat students fairly, are interested in } \\
\text { students' well-being, and students get along well with most teachers }\end{array}$ \\
\hline $\operatorname{srl}_{i j}$ & $\begin{array}{l}\text { Student interpersonal relations (IRT). Students respond to three ordinal items referring } \\
\text { to student-to-student relations. Higher scores indicate more positive interpersonal } \\
\text { relationships between students, where more students treat each other with respect and } \\
\text { get along, and where students feel safe }\end{array}$ \\
\hline
\end{tabular}

Notes IRT refers to item response theory weighted least estimates scores. These are continuous measures with a mean of 50 and standard deviation of 10 points, for equally weighted countries (Schulz et al. 2018b)

Source ICCS 2016 user guide (Köhler et al. 2018)

$$
\begin{aligned}
& +\pi_{5 j}^{[s]}\left(\operatorname{pol}_{i j}-\overline{p o l}_{. j k}\right)+\pi_{6 j}^{[s]}\left(\operatorname{soc}_{i j}-\overline{s o c}_{. j k}\right) \\
& +\pi_{7 j}^{[s]}\left(\operatorname{opd}_{i j}-\overline{o p d}_{. j k}\right)+\pi_{8 j}^{[s]}\left(\operatorname{cln}_{i j}-\overline{c l n}_{. j k}\right) \\
& +\pi_{9 j}^{[s]}\left(\operatorname{par}_{i j}-\overline{p a r}_{. j k}\right)+\pi_{10 j}^{[s]}\left(\operatorname{rel}_{i j}-\overline{r e l}_{. j k}\right) \\
& +\pi_{11 j}^{[s]}\left(\operatorname{srl}_{i j}-\overline{s r l}_{. j k}\right)
\end{aligned}
$$

In this notation $c n_{i j}$ represents the citizenship norms profiles, the "r" represents the comprehensive profile, and "s" represents the rest of the citizenship profiles. We conditioned the outcome on student variables $\left(x_{i j}\right)$, and aggregated variables as school means $\left(x_{. j}\right)$. We use subscripts $\ldots i j$ for zvariables referring to students' values nested in $\ldots j$ schools. Because we are fitting a model where the variance is divided in three parts, we use the subscripts ...jk to refer to schools within countries. In this model, the intercept term $\pi_{0 j}^{[s]}$ also depends on the term $r_{0 j}$ (see Eq. 2). This is a normally distributed random variable of mean 0 , and variance $\tau_{00}^{2}$. This latent variable is used to structure the school random intercepts and is obtained by specifying a common factor model over the school category random intercepts. This specification alleviates model estimation (Asparouhov and Muthén 2008; Vermunt 2003).

All continuous variables were first standardized and left with a mean of 0 and a standard deviation of 1 . Thus, a unit expresses a standard deviation of an attribute 
over the pooled mean between countries. Then, all selected variables were school centered, after centering all values at the grand mean of each country. With this centering approach we separate the variance of the dependent variable in three parts: the within school variance, the between school variance, and the country variance (Brincks et al. 2017; Rights et al. 2019). At the student level, the fitted model produces the average change in log odds ratio between the target category "s," and the reference category "r," across all schools. At the school level, the model produces estimates that express the specific change in log odds in the school intercepts for each comparison between the target category and the reference category (McNeish et al. 2017).

In the school level equation (see Eq. 2), we include aggregated scores of all variables as school means centered at the country mean. These variables do not contain any country variance (Brincks et al. 2017). Thus, to account for country differences 23 dummy coded variables were introduced in the model, leaving Lithuania as the reference category for the model intercepts $\left(\beta_{00}^{[s]}\right)$. This country presents a proportion of students with a comprehensive citizenship norm profile similar to the average of proportion across all countries.

$$
\begin{aligned}
\pi_{0 j}^{[s]}= & \beta_{00}^{[s]}+\beta_{01}^{[s]}\left(\overline{\operatorname{ses}}_{j k}-\overline{\operatorname{ses}}_{\ldots}\right)+\beta_{02}^{[s]}\left(\overline{\operatorname{sex}}_{j k}-\overline{\operatorname{sex}}_{\ldots}\right)+\beta_{03}^{[s]}\left(\overline{\mathrm{imm}}_{j k}-\overline{\mathrm{imm}}_{\ldots}\right) \\
& +\beta_{04}^{[s]}\left(\overline{\mathrm{int}}_{j k}-\overline{\overline{i n t}}_{\ldots}\right)+\beta_{05}^{[s]}\left(\overline{\operatorname{pol}}_{j k}-\overline{p o l}_{\ldots}\right)+\beta_{06}^{[s]}\left(\overline{\operatorname{soc}}_{j k}-\overline{\operatorname{soc}}_{\ldots}\right) \\
& +\beta_{07}^{[s]}\left(\overline{\mathrm{opd}}_{j k}-\overline{\mathrm{opd}}_{\ldots}\right)+\beta_{08}^{[s]}\left(\overline{\operatorname{cln}}_{j k}-\overline{\operatorname{cln}}_{\ldots}\right)+\beta_{09}^{[s]}\left(\overline{p a r}_{j k}-\overline{p a r}_{\ldots}\right) \\
& +\beta_{10}^{[s]}\left(\overline{\operatorname{rel}}_{j k}-\overline{\operatorname{rel}}_{\ldots}\right)+\beta_{11}^{[s]}\left(\overline{\operatorname{srl}}_{j k}-\overline{\operatorname{srl}}_{\ldots}\right)+\delta_{1-23}^{[s]} D_{k}+r_{0 j}
\end{aligned}
$$

To study student factors and their associations at the school level, we also calculate "contextual effects." These are differences between schools, not accounted for by students composition (Castellano et al. 2014), and represent the additional gains or losses to the outcome under study, conditional to the school levels of a factor. With the present model, we obtain these estimates as the subtraction of the between school estimates by its student level estimates (Willms 2010). For example, to get the contextual effect of SES we calculate $\beta_{01}^{[\mathrm{s}]}-\pi_{1 j}^{[\mathrm{s}]}$. We assess the contextual effect for SES, political interest, political discussion outside the school, political media use, student participation in the school, and teacher and students' interpersonal relations.

In the present study, students give responses regarding their school experience (see Table 2). This includes measures of open classroom discussion, civic learning at school, teacher-student relationships, and students' interpersonal relationships. We interpret the first two measures as reflective measures of the school environment (Stapleton et al. 2016). This implies that student responses from the same school are informative as a whole, because students from the same school referred to the same target. In this scenario, students act as informants of their own learning environment, and for these variables we are interested in their school level estimates $\left(\beta_{07}^{[\mathrm{s}]}, \beta_{08}^{[\mathrm{s}]}\right)$ (Lüdtke et al. 2009). The within estimates of these variables are out of the scope of interest, because these represent the level 1 climate residuals, or "informant differences" and not construct expected differences (Marsh et al. 2012). In contrast, teacher-student relations and students' interpersonal relationships can be interpreted 
as the personal experience of students, and also as the collective experience of the students from the same school. As such, within and between estimates are of interest for our research questions.

All estimations were carried out using Mplus 8.4 (Muthén and Muthén 2017). To assess overall model fit we recur to an adjusted likelihood ratio test (adj. LRT), that accompany the MLR estimator in MPLUS (Masyn 2014). This index assesses if the reduction in deviance is statistically significant. Additionally, we use the proportional change in variance (PCV) as a relative measure of accounted variance between models (Merlo et al. 2006). To assess school variability, in the odds ratio scale, we used the median odds ratio (MOR) (Merlo et al. 2006). This is a measure of how much the odds between the base category and a target category may change for similar observations, with different school membership. It varies from one to more than one. If MOR $=1$, then schools are unlikely to explain student's citizenship norms profiles. If MOR > 1, then schools' environments are related to how students endorse citizenship norms.

Survey weights were partitioned into student and school levels, and scaled to the effective samples while including pseudo strata in model estimation (Stapleton 2013). This procedure scales survey weights to one, at the student and school levels among all countries, thus allowing all countries to equally contribute to the estimates.

Results from the fitted model are described in terms of odds. This is the ratio between the probability of each profile in comparison to the "comprehensive" profile, conditional to one unit increase of any covariate. The results present overall model fit, and school variability, and then continues by presenting student and school level estimates, presenting model terms, odd ratios, and p-values (see Table 3 for student variables and Table 4 for school variables).

\subsection{Results}

Model fit and school variance. We compare the null model without predictors, with the model with all the proposed covariates using an adjusted likelihood ratio test (adj. LRT). The addition of the selected variables included in the model increases model fit, in contrast to the fully null model (adj. LRT $(180)=30,099.19 \mathrm{p}<0.01)$. The school level variance for the fully null model $\left(\tau_{00}^{2}=0.66, \mathrm{SE}=0.06, \mathrm{p}<0.001\right)$, diminishes when country fixed effects are introduced in the model $\left(\tau_{00}^{2}=0.21, \mathrm{SE}=0.04, \mathrm{p}\right.$ $<0.001)$. This last estimate consists of the school level variability not accounted for by country differences. The median odds ratio (MOR) of this model (MOR = 1.55, CI95 [1.43, 1.66]), indicates that citizenship norms endorsement changes 1.5 times due to school membership. The school-level variance diminishes when the selected variables are introduced in the model $\left(\tau_{00}^{2}=0.12, \mathrm{SE}=0.02, \mathrm{p}<0.001\right)$. The proportional change in variance from the country fixed effect model, in contrast to the model with all proposed variables is considerable $(\mathrm{PCV}=43 \%)$, where more than $40 \%$ of the variance left is accounted by the selected school covariates. 
Table 3 Student level multinomial logit estimates explaining the odds of the citizenship norms profiles over the comprehensive profile

\begin{tabular}{|c|c|c|c|c|c|c|c|c|}
\hline \multirow[t]{2}{*}{ Param. } & \multirow[t]{2}{*}{ Covariates } & \multicolumn{4}{|c|}{ Socially-engaged } & \multicolumn{3}{|c|}{ Duty-based } \\
\hline & & $\mathrm{E}$ & OR & \multicolumn{2}{|l|}{$\mathrm{p}<$} & $\mathrm{E}$ & OR & $\mathrm{p}<$ \\
\hline$\pi_{1 j}^{[s]}$ & SES & 0.06 & 1.06 & \multicolumn{2}{|l|}{$*$} & -0.01 & 0.99 & \\
\hline$\pi_{2 j}^{[s]}$ & Female & 0.22 & 1.24 & \multicolumn{2}{|l|}{$* * *$} & -0.09 & 0.91 & \\
\hline$\pi_{3 j}^{[s]}$ & Immigrant & -0.08 & 0.93 & & & -0.04 & 0.96 & \\
\hline$\pi_{4 j}^{[s]}$ & Political interest & -0.50 & 0.61 & \multicolumn{2}{|l|}{$* * *$} & -0.50 & 0.60 & $* * *$ \\
\hline$\pi_{5 j}^{[s]}$ & $\begin{array}{l}\text { Political } \\
\text { discussion }\end{array}$ & -0.05 & 0.95 & & & -0.07 & 0.94 & \\
\hline$\pi_{6 j}^{[s]}$ & $\begin{array}{l}\text { Political social } \\
\text { media use }\end{array}$ & -0.18 & 0.84 & $* * *$ & & -0.13 & 0.87 & $* *$ \\
\hline$\pi_{7 j}^{[s]}$ & $\begin{array}{l}\text { Open classroom } \\
\text { discussion }\end{array}$ & -0.09 & 0.91 & $* *$ & & -0.17 & 0.84 & $* * *$ \\
\hline$\pi_{8 j}^{[s]}$ & Civic learning & -0.14 & 0.87 & $* * *$ & & -0.27 & 0.76 & $* * *$ \\
\hline$\pi_{9 j}^{[s]}$ & $\begin{array}{l}\text { Students } \\
\text { participation }\end{array}$ & -0.06 & 0.94 & $*$ & & -0.16 & 0.85 & $* *$ \\
\hline$\pi_{10 j}^{[s]}$ & $\begin{array}{l}\text { Teacher-student } \\
\text { relations }\end{array}$ & -0.11 & 0.90 & $* *$ & & -0.23 & 0.80 & $* * *$ \\
\hline$\pi_{11 j}^{[s]}$ & $\begin{array}{l}\text { Student } \\
\text { interpersonal } \\
\text { relations }\end{array}$ & -0.10 & 0.90 & $* * *$ & \multicolumn{2}{|c|}{-0.05} & 0.95 & \\
\hline Param. & Covariates & & Monito & & & Anom & & \\
\hline & & & E & OR & $\mathrm{p}<$ & $\mathrm{E}$ & OR & $\mathrm{p}<$ \\
\hline$\pi_{1 j}^{[s]}$ & SES & & -0.04 & 0.96 & & -0.09 & 0.91 & \\
\hline$\pi_{2 j}^{[s]}$ & Female & & -0.19 & 0.83 & $*$ & -0.54 & 0.58 & $* * *$ \\
\hline$\pi_{3 j}^{[s]}$ & Immigrant & & 0.04 & 1.04 & & 0.04 & 1.04 & \\
\hline$\pi_{4 j}^{[s]}$ & Political interest & & -0.54 & 0.58 & $* * *$ & -0.69 & 0.50 & $* *$ \\
\hline$\pi_{5 j}^{[s]}$ & Political discussion & & -0.05 & 0.95 & & -0.37 & 0.69 & $* * *$ \\
\hline$\pi_{6 j}^{[s]}$ & Political social mec & use & -0.03 & 0.97 & & -0.35 & 0.71 & $* * *$ \\
\hline$\pi_{7 j}^{[s]}$ & Open classroom di & ussion & -0.20 & 0.82 & $* * *$ & -0.21 & 0.81 & $* *$ \\
\hline$\pi_{8 j}^{[s]}$ & Civic learning & & -0.39 & 0.68 & $* * *$ & -0.67 & 0.51 & $* * *$ \\
\hline$\pi_{9 j}^{[s]}$ & Students participati & & -0.08 & 0.93 & $*$ & -0.26 & 0.77 & $* *$ \\
\hline$\pi_{10 j}^{[s]}$ & Teacher-student rel & ions & -0.35 & 0.71 & $* * *$ & -0.70 & 0.50 & $* * *$ \\
\hline$\pi_{11 j}^{[s]}$ & Student interperson & 1 relations & -0.17 & 0.84 & $* * *$ & -0.06 & 0.95 & \\
\hline
\end{tabular}

Notes Param. $=$ Equation parameters $; \mathrm{E}=$ Estimated multinomial logits for the odds ratio between the target category and the reference category (comprehensive), $\mathrm{OR}=$ Odds ratio, $* * *=p<0.001$, $* *=\mathrm{p}<0.01, *=\mathrm{p}<0.05$ 
Table 4 School characteristics retrieved from students' responses explaining citizenship norms endorsement profiles

\begin{tabular}{|c|c|c|c|c|c|c|c|}
\hline \multirow[t]{2}{*}{ Param. } & \multirow[t]{2}{*}{ Covariates } & \multicolumn{3}{|c|}{ Socially engaged } & \multicolumn{3}{|c|}{ Duty-based } \\
\hline & & E & OR & $\mathrm{p}<$ & E & OR & $\mathrm{p}<$ \\
\hline$\beta_{01}^{[s]}$ & School SES & 0.30 & 1.35 & $* * *$ & 0.30 & 1.36 & $* * *$ \\
\hline$\beta_{02}^{[s]}$ & School proportion of females & 0.41 & 1.50 & $*$ & 0.18 & 1.19 & \\
\hline$\beta_{03}^{[s]}$ & School proportion of immigrants & -0.16 & 0.85 & & 0.55 & 1.72 & \\
\hline$\beta_{04}^{[s]}$ & Political interest & -1.17 & 0.31 & $* * *$ & -0.18 & 0.84 & \\
\hline$\beta_{05}^{[s]}$ & Political discussion & 0.28 & 1.32 & & 0.07 & 1.07 & \\
\hline$\beta_{06}^{[s]}$ & Political social media use & -0.38 & 0.69 & $*$ & -0.84 & 0.43 & $* *$ \\
\hline$\beta_{07}^{[s]}$ & Open classroom discussion & -0.15 & 0.86 & & -0.08 & 0.92 & \\
\hline$\beta_{08}^{[s]}$ & Civic learning & -0.24 & 0.79 & $*$ & -0.66 & 0.52 & $* * *$ \\
\hline$\beta_{09}^{[s]}$ & Student participation & 0.03 & 1.03 & & 0.01 & 1.01 & \\
\hline$\beta_{10}^{[s]}$ & Teacher-student relations & 0.08 & 1.09 & & -0.11 & 0.90 & \\
\hline$\beta_{11}^{[s]}$ & Student interpersonal relations & -0.30 & 0.74 & $*$ & -0.16 & 0.85 & \\
\hline$\beta_{00}^{[s]}$ & Intercept & -0.24 & 0.79 & $* *$ & -0.44 & 0.65 & $* * *$ \\
\hline \multirow[t]{2}{*}{ Param. } & Covariates & \multicolumn{3}{|c|}{ Monitorial } & \multicolumn{3}{|c|}{ Anomic } \\
\hline & & E & OR & $\mathrm{p}<$ & E & OR & $\mathrm{p}<$ \\
\hline$\beta_{01}^{[s]}$ & School SES & -0.08 & 0.93 & & -0.13 & 0.88 & \\
\hline$\beta_{02}^{[s]}$ & School proportion of females & 0.07 & 1.07 & & -0.78 & 0.46 & $*$ \\
\hline$\beta_{03}^{[s]}$ & School proportion of immigrants & 0.73 & 2.08 & $*$ & 1.08 & 2.95 & $*$ \\
\hline$\beta_{04}^{[s]}$ & Political interest & -0.94 & 0.39 & $*$ & -1.08 & 0.34 & \\
\hline$\beta_{05}^{[s]}$ & Political discussion & 0.30 & 1.35 & & -0.13 & 0.88 & \\
\hline$\beta_{06}^{[s]}$ & Political social media use & 0.00 & 1.00 & & -0.13 & 0.88 & \\
\hline$\beta_{07}^{[s]}$ & Open classroom discussion & -0.56 & 0.57 & $* * *$ & -0.69 & 0.50 & $* *$ \\
\hline$\beta_{08}^{[s]}$ & Civic learning & -0.71 & 0.49 & $* * *$ & -1.13 & 0.32 & $* * *$ \\
\hline$\beta_{09}^{[s]}$ & Student participation & 0.26 & 1.29 & & -0.28 & 0.76 & \\
\hline$\beta_{10}^{[s]}$ & Teacher-student relations & -0.20 & 0.82 & & -0.27 & 0.76 & \\
\hline$\beta_{11}^{[s]}$ & Student interpersonal relations & -0.40 & 0.67 & $* *$ & -0.57 & 0.57 & $*$ \\
\hline$\beta_{00}^{[s]}$ & Intercept & -1.31 & 0.27 & $* * *$ & -3.51 & 0.03 & $* * *$ \\
\hline
\end{tabular}

Notes Param. $=$ Equation parameters $; \mathrm{E}=$ Estimated multinomial logits for the odds ratio between the target category and the reference category (comprehensive), $\mathrm{OR}=$ Estimates expressed as odds ratio, $* * *=\mathrm{p}<0.001, * *=\mathrm{p}<0.01, *=\mathrm{p}<0.05$ 
Student characteristics. Student characteristics can be divided into sociodemographic and civic background variables (Table 1). Among the first, gender presents the largest odds. Across schools, female students are less likely to endorse citizenship norms in an anomic way (OR $=-0.58, \mathrm{p}<0.001)$, and to display a monitorial profile $(\mathrm{OR}=0.83, \mathrm{p}<0.05)$, in contrast to the base category. Complementarily, female students are more likely to endorse citizenship norms with a socially-engaged profile than a comprehensive profile $(\mathrm{OR}=1.24, \mathrm{p}<0.001)$. We observed a small relationship between students' SES and the endorsement of the socially-engaged profile $(\mathrm{OR}=1.06, \mathrm{p}<0.05)$, and having an immigrant background is not related to any of the presented profiles.

In terms of students' civic background, the factor with the largest association to the endorsement of citizenship profiles is political interest. Across schools, students with high political interest are less likely to endorse any of the citizenship norms profiles in comparison to the comprehensive profile. If we reverse the estimated odds, this means that students with political interest are two times more likely to present a comprehensive profile instead of an anomic profile $(\mathrm{OR}=0.50, \mathrm{p}<0.01,1 / \mathrm{OR}=$ 2.00), 1.72 times more likely to present comprehensive instead of the monitorial $(\mathrm{OR}=0.58, \mathrm{p}<0.001,1 / \mathrm{OR}=1.72), 1.67$ times more likely to be comprehensive instead of duty-based $(\mathrm{OR}=0.60, \mathrm{p}<0.001,1 / \mathrm{OR}=1.67)$, and 1.64 times more likely to be comprehensive instead of socially engaged $(\mathrm{OR}=0.61, \mathrm{p}<0.001,1 / \mathrm{OR}$ $=1.64$ ). Complementary, students who engage more in political discussions outside their school present 1.43 chances to endorse citizenship norms in a comprehensive way instead of presenting an anomic profile $(\mathrm{OR}=0.69, \mathrm{p}<0.001,1 / \mathrm{OR}=1.43)$. In general, students who use more frequently social media to read and post about political and social issues present lower chances to present an anomic profile (OR $=0.71, \mathrm{p}<0.001,1 / \mathrm{OR}=1.41)$, or socially engaged $(\mathrm{OR}=0.84, \mathrm{p}<0.001$, $1 / \mathrm{OR}-1=1.19)$, or duty-based $(\mathrm{OR}=0.87, \mathrm{p}<0.01,1 / \mathrm{OR}=1.15)$ in contrast to the comprehensive profile. Thus, in general, the comprehensive profile is associated with a higher political interest than the rest of the student citizenship norms profiles.

In general, across schools, students who participate more in political activities at school are more likely to present a comprehensive citizenship norms endorsement. Students who are more participative present larger odds of being comprehensive instead of anomic $(\mathrm{OR}=0.77, \mathrm{p}<0.01,1 / \mathrm{OR}=1.30)$, comprehensive instead of duty-based $(\mathrm{OR}=0.85, \mathrm{p}<0.01,1 / \mathrm{OR}=1.18)$, comprehensive instead of monitorial $(\mathrm{OR}=0.93, \mathrm{p}<0.05,1 / \mathrm{OR}=1.08)$, and comprehensive instead of socially engaged $(\mathrm{OR}=0.94, \mathrm{p}<0.05,1 / \mathrm{OR}=1.06)$. As such, it seems that participation at school seems to prevent students from presenting citizenship norms profiles concentrated mainly on some norms.

Students' personal experiences at school are also related to their citizenship norms endorsement. Across schools, students who report more positive teacher-student relations are less likely to endorse the anomic profile $(\mathrm{OR}=0.50, \mathrm{p}<0.001,1 / \mathrm{OR}$ $=2.00)$, the monitorial profile $(\mathrm{OR}=0.71, \mathrm{p}<0.001,1 / \mathrm{OR}=1.41)$, the duty-based profile $(\mathrm{OR}=0.80, \mathrm{p}<0.001,1 / \mathrm{OR}=1.25)$, and the socially-engaged profile ( $\mathrm{OR}$ $=0.90, \mathrm{p}<0.01,1 / \mathrm{OR}=1.11)$ in contrast to the comprehensive profile. Similarly, across schools, students who report more positive interpersonal relations with their 
peers at schools are less likely to present a monitorial profile $(\mathrm{OR}=0.84, \mathrm{p}<0.001$, $1 / \mathrm{OR}=1.19)$ and a socially-engaged profile $(\mathrm{OR}=0.90, \mathrm{p}<0.001,1 / \mathrm{OR}=1.11)$, both in contrast to the comprehensive profile. Thus, in general, attending a school where students have more positive relations with teachers and their peers is positively associated with a comprehensive endorsement of citizenship norms.

School level results. Table 2 includes the school level results. First, we review school composition variables. Higher school SES presents a positive association to endorsing socially-engaged citizenship norms ( $\mathrm{OR}=1.35, \mathrm{p}<0.001)$, and dutybased citizenship norms $(\mathrm{OR}=1.36, \mathrm{p}<0.001)$, in contrast to presenting a comprehensive profile. We assess if these associations are independent of students' SES levels, and indeed they are. School SES present contextual effects $\left(\beta_{01}^{[1]}-\pi_{1 j}^{[1]}=\right.$ $0.24, \mathrm{OR}=1.27, \mathrm{p}<0.01)$ for the socially-engaged profile, and for the duty-based profile $\left(\beta_{01}^{[2]}-\pi_{1 j}^{[2]}=0.32, \mathrm{OR}=1.37, \mathrm{p}<0.01\right)$. This means that students attending schools with a school SES of 1 standard deviation above each country mean, are 1.37 times more likely to endorse duty-based norms and 1.27 times more likely to endorse socially-engaged norms, in comparison to comprehensive citizenship norms. Consistently to student individual level effects, schools with a higher proportion of females are expected to present a higher proportion of students endorsing socially-engaged citizenship norms $(\mathrm{OR}=1.50, \mathrm{p}<0.05)$, instead of the comprehensive profile. Similarly, schools with a higher proportion of females are less likely to endorse citizenship norms via an anomic profile (OR $=0.46, \mathrm{p}<0.05)$. However, these two latter effects are not independent of the students' gender across schools (i.e., level 1 student gender coefficient). Finally, schools with a higher proportion of immigrant students are positively associated to students endorsing monitorial citizenship norms $(\mathrm{OR}=2.08, \mathrm{p}<0.05)$ and anomic citizenship norms $(\mathrm{OR}=2.95, \mathrm{p}<.0 .05)$, instead of the comprehensive profile. Yet, these effects are not larger than the student level estimates, and do not consist of contextual effects.

Higher levels of political interest, higher political discussion outside the school, and higher political social media use at school are associated with students' citizenship norms endorsement. Schools with higher levels of students' political interest present lower odds of students presenting socially-engaged citizenship norms (OR $=0.31, \mathrm{p}<0.001)$, instead of the comprehensive profile. This effect is larger than the student level estimates $\left(\beta_{04}^{[1]}-\pi_{4 j}^{[1]}=-0.67, \mathrm{OR}=0.51, \mathrm{p}<0.05\right)$, thus independent of students' political interest, schools with a higher average of student political interest seem to make students almost two times more likely to endorse citizenship norms via a comprehensive profile, instead of a socially-engaged profile (1/OR = $1.96, \mathrm{p}<0.05)$. Similarly, students in schools with a higher level of political interest between students have lower chances of endorsing citizenship norms via a monitorial profile $(\mathrm{OR}=0.39, \mathrm{p}<0.05)$. However, this association does not conform to a contextual effect. Additionally, political discussion among students outside of schools does not present associations for citizenship norms endorsement in a simple way. Independent of the individual student levels of political discussion outside school, schools with a higher mean of students discussing political issues outside the school are positively related to students endorsing monitorial norms $\left(\beta_{05}^{[3]}-\pi_{5 j}^{[3]}=0.35\right.$, OR $=$ $1.42, \mathrm{p}<0.05)$. Finally, schools with higher average levels of students' political use 
of social media are negatively associated to socially-engaged norms $(\mathrm{OR}=0.69, \mathrm{p}<$ $0.05)$, and duty-based norms $(\mathrm{OR}=0.43, \mathrm{p}<0.05)$, in contrast to a comprehensive citizenship norms endorsement. This latter association is a contextual effect $\left(\beta_{05}^{[2]}\right.$ $\left.-\pi_{5 j}^{[2]}=-0.70, \mathrm{OR}=0.49, \mathrm{p}<0.05\right)$. Thus, students in schools with high levels of political social media use among students are two times more likely to present a comprehensive citizenship norms profile instead of duty-based profile $(1 / \mathrm{OR}=2.04$, $\mathrm{p}<0.05)$.

Regarding the school experience variables, schools with more positive interpersonal relations between students have higher chances to present students with comprehensive citizenship profiles instead of anomic $(\mathrm{OR}=0.57 \mathrm{p}<0.05,1 / \mathrm{OR}=$ $1.75)$, monitorial $(\mathrm{OR}=0.67, \mathrm{p}<0.01,1 / \mathrm{OR}=1.49)$, and instead of socially-engaged profiles $(\mathrm{OR}=0.74, \mathrm{p}<0.05,1 / \mathrm{OR}=1.35)$. Additionally, schools with higher levels of student participation have lower chances to present monitorial profiles instead of comprehensive profiles, regardless of the students' levels of participation $\left(\beta_{09}^{[3]}-\pi_{9 j}^{[3]}\right.$ $=0.33$, OR $=1.40, \mathrm{p}<0.05)$.

Schools with higher civic learning (that is schools with more opportunities to learn how to vote in local and national elections, how laws are introduced in their country, and learn about citizens' rights) have higher chances of students endorsing citizenship norms via a comprehensive profile instead of any other citizenship norms profile. Students with a higher exposure to civic learning opportunities present 3.13 times more chances to endorse citizenship norms via a comprehensive profile instead of an anomic profile $(\mathrm{OR}=0.32, \mathrm{p}<0.001,1 / \mathrm{OR}=3.13), 2.04$ times more instead of presenting a monitorial profile $(\mathrm{OR}=0.49, \mathrm{p}<0.01,1 / \mathrm{OR}=2.04), 1.92$ times more likely instead of a duty-based profile ( $\mathrm{OR}=0.52, \mathrm{p}<0.001,1 / \mathrm{OR}=1.92$ ), and 1.27 times more chances of students presenting a comprehensive profile instead of a socially-engaged profile $(\mathrm{OR}=0.79, \mathrm{p}<0.05,1 / \mathrm{OR}=1.27)$. Additionally, schools with higher levels of open classroom discussion present lower chances to have students from the monitorial $(\mathrm{OR}=0.57, \mathrm{p}<0.001,1 / \mathrm{OR}=1.75)$ and anomic profiles $(\mathrm{OR}=0.50, \mathrm{p}<0.01,1 / \mathrm{OR}=2.00)$. Students in schools with one standard deviation more of open classroom discussion are two times more likely to present a comprehensive citizenship norms profile, instead of an anomic profile and 1.75 more chances of having a comprehensive profile versus a monitorial profile.

\subsection{Conclusions}

In the present chapter, we inquire if school membership is associated with students' citizenship norms endorsement. Our results are positive, students from different schools present different citizenship norms profiles. Using meta-analytic formulas, we can express the median odds ratio in terms of effect size (Borenstein et al. 2009). A median odds ratio of 1.55 is equivalent to an effect size of $r=0.12$. The second inquiry concerned if observed school practices, in particular civic learning at schools and open classroom discussion, are related to citizenship norms endorsement. These 
two school processes promote the endorsement of citizenship norms in a comprehensive way, instead of other partial endorsement of citizenship norms. The sizes of these associations are greater than for students' sociodemographic background, students' civic background, and other school attributes. Additionally, if there is Level 2 endogeneity of schools' composition via student SES, the present estimates can be regarded as lower bound effects, because mixed models present downward bias for the estimates of school practices (Castellano et al. 2014). In summary, students in schools that provide more opportunities to learn and discuss political and social issues in their classroom guided by their teacher are more likely to endorse all included citizenship norms. These norms refer to voting in national elections, discussing politics, working hard, obeying the law, respecting authorities, protesting against unjust laws, promoting human rights, and participating in the local community for the benefit of others.

In the study we also observed different contextual effects. These are expected changes in odds regardless of students' characteristics. Schools with higher means of SES are more likely to present students with partial endorsement of the selected citizenship norms. Higher SES schools presented higher odds for socially-engaged and duty-based norms, instead of the comprehensive norms. We assume these differences are the product of non-observed school attributes (Alwin 1976), because these are the expected odds of endorsing a set of citizenship norms regardless of students' SES. However, contextual effects could be driven by other mechanisms such as school segregation and peer effects (Collado et al. 2014; Isac et al. 2014). A pure school segregation effect means that students are so different between schools in terms of SES, that all students from the same school are almost equivalent regarding SES. In this scenario, all differences between students in the population will be absorbed as a between school effect in a multilevel model. Peer effects imply there is no school environment attribute which can explain why schools with more affluent intake present larger estimates than the within school estimates. Thus, it is the exposure to more affluent students that would drive the estimated effect. These two later explanations seem unlikely, while the unmeasured factor assumption implies that schools with a higher SES intake, across all countries, may not promote all citizenship norms equally by an unknown mechanism. This finding requires further research to provide a sensible explanation.

Additionally, we observed three other contextual effects independent of students' characteristics. Schools with students with higher political interest present higher chances of endorsing comprehensive citizenship norms, instead of socially-engaged norms. Students in schools with students who use more social media to find and share political content are less likely endorse duty-based norms, in contrast to endorsing all citizenship norms. Thus, more politicized school environments seems to prevent student endorsement of two of the profiles that express more political apathy (Dahl et al. 2018). A divergent result with this pattern is that schools with students who discuss political issues with friends and family are positively associated with monitorial citizenship endorsement versus its comprehensive counterpart. Higher political discussion among peers in the school may promote a more critical view of the political system and may lead to greater monitorial norms endorsement (Amnå and Ekman 
2014; Hooghe and Dejaeghere 2007). These associations are independent of students own political interest, political social media use, and political discussion outside the school.

The specific experience of students within schools, in terms of their interpersonal relationships with teachers is a positive factor for the endorsement of citizenship norms in a comprehensive way. These results are consistent with previous literature that highlights the relevance of the interpersonal climate in schools as a fundamental factor for citizenship development (Claes et al. 2017; Sampermans et al. 2018).

Finally, confronted with the question of what kind of citizens are promoting our schools, the citizenship norms literature has distinguished between citizens who follow the rule of law, pay taxes, and are willing to vote, in contrast to citizens more involved with the community. This is the contrast between the "duty-based" and the distinctively "engaged" citizenship (Dalton 2008; Hooghe and Oser 2015; Hooghe et al. 2016). The "duty-based" citizen obeys the law and endorses the formal channels of participation, such as participating in national elections. While the "engaged" citizen disregards the formal channels of political participation, but highly endorses the importance of protecting human rights and involvement with the local community (Hooghe et al. 2016). Neither of these two profiles alone seem enough to support a well-functioning democracy. Schools that provided higher civic learning opportunities, more frequent open classroom discussion, and more participatory environments promote a more comprehensive citizenship endorsement. These are students who simultaneously endorse compliance to the law, participation in national elections, valuing political interest, and protest against unjust laws. These are students who might be convinced that they can influence the government to defend the rights of others (Crick 2007) from authoritarian measures from governments, even in the most consolidated democracies of the world.

Acknowledgements The authors would like to thank the sponsorship of the Center for Educational Justice ANID PIA CIE160007, as well as the Chilean National Agency of Research and Development through the grant ANID/FONDECYT N ${ }^{\circ} 1180667$.

\section{References}

Alwin, D. F. (1976). Assessing school effects: Some identities. Sociology of Education, 49(4), 294. https://doi.org/10.2307/2112315.

Amnå, E., \& Ekman, J. (2014). Standby citizens: Diverse faces of political passivity. European Political Science Review, 6(2). https://doi.org/10.1017/S175577391300009X.

Asparouhov, T., \& Muthén, B. (2008). Multilevel mixture models. In G. R. Hancock \& K. M. Samuelsen (Eds.), Advances in latent variable mixture models (pp. 27-51). Information Age Publishing Inc.

Bickmore, K. (2001). Student conflict resolution, power "sharing" in schools, and citizenship education. Curriculum Inquiry, 31(2), 137-162. https://doi.org/10.1111/0362-6784.00189.

Biesta, G., Lawy, R., \& Kelly, N. (2009). Understanding young people's citizenship learning in everyday life. Education, Citizenship and Social Justice, 4(1), 5-24. https://doi.org/10.1177/174 6197908099374. 
Borenstein, M., Hedges, L. V., Higgins, J. P. T., \& Rothstein, H. R. (2009). Introduction to metaanalysis. West Sussex, United Kingdom: John Wiley \& Sons, Ltd.

Brincks, A. M., Enders, C. K., Llabre, M. M., Bulotsky-Shearer, R. J., Prado, G., \& Feaster, D. J. (2017). Centering predictor variables in three-level contextual models. Multivariate Behavioral Research, 52(2), 149-163. https://doi.org/10.1080/00273171.2016.1256753.

Campbell, D. E. (2008). Voice in the classroom: How an open classroom climate fosters political engagement among adolescents. Political Behavior, 30(4), 437-454. https://doi.org/10.1007/s11 109-008-9063-z.

Caro, D. H., \& Schulz, W. (2012). Ten hypotheses about tolerance toward minorities among Latin American adolescents. Citizenship, Social and Economics Education, 11(3), 213-234. https:// doi.org/10.2304/csee.2012.11.3.213.

Carrasco, D., \& Torres Irribarra, D. (2018). The role of classroom discussion. In A. SandovalHernández, M. M. Isac, \& D. Miranda (Eds.), Teaching tolerance in a globalized world (pp. 87 101). IEA Research for Education series. Cham, Switzerland: Springer. https://doi.org/10.1007/ 978-3-319-78692-6.

Castellano, K. E., Rabe-Hesketh, S., \& Skrondal, A. (2014). Composition, context, and endogeneity in school and teacher comparisons. Journal of Educational and Behavioral Statistics, 39(5), 333-367. https://doi.org/10.3102/1076998614547576.

Castillo, J. C., Miranda, D., Bonhomme, M., Cox, C., \& Bascope, M. (2014). Social inequality and changes in students' expected political participation in Chile. Education, Citizenship and Social Justice, 9(2), 140-156. https://doi.org/10.1177/1746197914520650.

Cialdini, R. B., \& Goldstein, N. J. (2004). Social influence: Compliance and conformity. Annual Review of Psychology, 55(1), 591-621. https://doi.org/10.1146/annurev.psych.55.090902. 142015.

Claes, E., Maurissen, L., \& Havermans, N. (2017). Let's talk politics: Which individual and classroom compositional characteristics matter in classroom discussions? Young, 25(4_suppl), 18S-35S. https://doi.org/10.1177/1103308816673264.

Coffé, H., \& van der Lippe, T. (2010). Citizenship norms in Eastern Europe. Social Indicators Research, 96(3), 479-496. https://doi.org/10.1007/s11205-009-9488-8.

Collado, D., Lomos, C., \& Nicaise, I. (2014). The effects of classroom socioeconomic composition on student's civic knowledge in Chile. School Effectiveness and School Improvement, (January 2015), 1-26. https://doi.org/10.1080/09243453.2014.966725.

Crick, B. (2007). Citizenship: the political and the democratic. British Journal of Educational Studies, 55(3), 235-248. https://doi.org/10.1111/j.1467-8527.2007.00377.x.

Dahl, V., Amnå, E., Banaji, S., Landberg, M., Šerek, J., Ribeiro, N., \& Zani, B. (2018). Apathy or alienation? Political passivity among youths across eight European Union countries. European Journal of Developmental Psychology, 15(3), 284-301. https://doi.org/10.1080/17405629.2017. 1404985.

Dalton, R. J. (2008). Citizenship norms and the expansion of political participation. Political Studies, 56(1), 76-98. https://doi.org/10.1111/j.1467-9248.2007.00718.x.

Dassonneville, R., Quintelier, E., Hooghe, M., \& Claes, E. (2012). The relation between civic education and political attitudes and behavior: A two-year panel study among Belgian late adolescents. Applied Developmental Science, 16(3), 140-150. https://doi.org/10.1080/10888691.2012. 695265.

Denters, S. A. H., Gabriel, O., \& Torcal, M. (2007). Norms of good citizenship. In J. W. van Deth, J. R. Montero, \& A. Westholm (Eds.), Citizenship and involvement in European democracies: A comparative analysis (pp. 87-108). https://doi.org/10.4324/9780203965757-12.

Heyneman, S. P. (2000). From the party/state to multiethnic democracy: Education and social cohesion in europe and Central Asia. Educational Evaluation and Policy Analysis, 22(2), 173 191. https://doi.org/10.3102/01623737022002173.

Hooghe, M., \& Dassonneville, R. (2013). Voters and candidates of the future: The intention of electoral participation among adolescents in 22 European countries. Young, 21(1), 1-28. https:// doi.org/10.1177/1103308812467664. 
Hooghe, M., \& Dejaeghere, Y. (2007). Does the "monitorial citizen" exist? An empirical investigation into the occurrence of postmodern forms of citizenship in the nordic countries. Scandinavian Political Studies, 30(2), 249-271. https://doi.org/10.1111/j.1467-9477.2007.00180.x.

Hooghe, M., \& Oser, J. (2015). The rise of engaged citizenship: The evolution of citizenship norms among adolescents in 21 countries between 1999 and 2009. International Journal of Comparative Sociology, 56(1), 29-52. https://doi.org/10.1177/0020715215578488.

Hooghe, M., Oser, J., \& Marien, S. (2016). A comparative analysis of 'good citizenship': A latent class analysis of adolescents' citizenship norms in 38 countries. International Political Science Review, 37(1), 115-129. https://doi.org/10.1177/0192512114541562.

Hoskins, B., Janmaat, J. G., \& Melis, G. (2017). Tackling inequalities in political socialisation: A systematic analysis of access to and mitigation effects of learning citizenship at school. Social Science Research, 68, 88-101. https://doi.org/10.1016/j.ssresearch.2017.09.001.

Isac, M. M., Maslowski, R., Creemers, B., \& van der Werf, G. (2014). The contribution of schooling to secondary-school students' citizenship outcomes across countries. School Effectiveness \& School Improvement, 25(January 2015), 29-63. https://doi.org/10.1080/09243453.2012.751035.

Jansen, T., Chioncel, N., \& Dekkers, H. (2006). Social cohesion and integration: Learning active citizenship. British Journal of Sociology of Education, 27(2), 189-205. https://doi.org/10.1080/ 01425690600556305 .

Kahne, J., Crow, D., \& Lee, N. J. (2013). Different pedagogy, different politics: High school learning opportunities and youth political engagement. Political Psychology, 34(3), 419-441. https://doi. org/10.1111/j.1467-9221.2012.00936.x.

Kahne, J., \& Sporte, S. E. (2008). Developing citizens: The impact of civic learning opportunities on students' commitment to civic participation. American Educational Research Journal, 45(3), 738-766. https://doi.org/10.3102/0002831208316951.

Kankaraš, M., \& Vermunt, J. K. (2015). Simultaneous latent-class analysis across groups. Encyclopedia of Quality of Life and Well-Being Research, 1974, 5969-5974. https://doi.org/10.1007/ 978-94-007-0753-5_2711.

Knowles, R. T., Torney-Purta, J., \& Barber, C. (2018). Enhancing citizenship learning with international comparative research: Analyses of IEA civic education datasets. Citizenship Teaching and Learning, 13(1), 7-30. https://doi.org/10.1386/ctl.13.1.7.

Köhler, H., Weber, S., Brese, F., Schulz, W., \& Carstens, R. (Eds.). (2018). ICCS 2016 user guide for the international database. Amsterdam, the Netherlands: International Association for the Evaluation of Educational Achievement (IEA).

Legros, S., \& Cislaghi, B. (2019). Mapping the social-norms literature: An overview of reviews. Perspectives on Psychological Science, 15-17,. https://doi.org/10.1177/1745691619866455.

Liu, H., Van Damme, J., Gielen, S., \& Van Den Noortgate, W. (2015). School processes mediate school compositional effects: model specification and estimation. British Educational Research Journal, 41(3), 423-447. https://doi.org/10.1002/berj.3147.

Lüdtke, O., Robitzsch, A., Trautwein, U., \& Kunter, M. (2009). Assessing the impact of learning environments: How to use student ratings of classroom or school characteristics in multilevel modeling. Contemporary Educational Psychology, 34(2), 120-131. https://doi.org/10.1016/j.ced psych.2008.12.001.

Marsh, H. W., Lüdtke, O., Nagengast, B., Trautwein, U., Morin, A. J. S., Abduljabbar, A. S., \& Köller, O. (2012). Classroom climate and contextual effects: Conceptual and methodological issues in the evaluation of group-level effects. Educational Psychologist, 47(2), 106-124. https:// doi.org/10.1080/00461520.2012.670488.

Martens, A. M., \& Gainous, J. (2013). Civic education and democratic capacity: How do teachers teach and what works? Social Science Quarterly, 94(4), 956-976. https://doi.org/10.1111/j.15406237.2012.00864.x.

Masyn, K. E. (2014). Discrete-time survival analysis in prevention science. In Z. Sloboda, \& H. Petras (Eds.), Defining prevention science (pp. 513-535). New York, NY: Springer. https://doi. org/10.1007/978-1-4899-7424-2. 
Masyn, K. E. (2017). Measurement invariance and differential item functioning in latent class analysis with stepwise multiple indicator multiple cause modeling. Structural Equation Modeling: A Multidisciplinary Journal, 24(2), 180-197. https://doi.org/10.1080/10705511.2016.1254049.

McNeish, D., Stapleton, L. M., \& Silverman, R. D. (2017). On the unnecessary ubiquity of hierarchical linear modeling. Psychological Methods, 22(1), 114-140. https://doi.org/10.1037/met000 0078.

Merlo, J., Chaix, B., Ohlsson, H., Beckman, A., Johnell, K., Hjerpe, P., \& Larsen, K. (2006). A brief conceptual tutorial of multilevel analysis in social epidemiology: using measures of clustering in multilevel logistic regression to investigate contextual phenomena. Journal of Epidemiology and Community Health, 60(4), 290-297. https://doi.org/10.1136/jech.2004.029454.

Muthén, L. K., \& Muthén, B. O. (2017). Mplus user's guide (8th ed.). . Muthén \& Muthén.

Patterson, M. M., Bigler, R. S., Pahlke, E., Brown, C. S., Hayes, A. R., Ramirez, M. C., \& Nelson, A. (2019). Toward a developmental science of politics. Monographs of the Society for Research in Child Development, 84(3), 7-185. https://doi.org/10.1111/mono.12410.

Persson, M. (2015). Classroom climate and political learning: findings from a Swedish panel study and comparative data. Political Psychology, 36(5), 587-601. https://doi.org/10.1111/pops.12179.

Quintelier, E. (2010). The effect of schools on political participation: a multilevel logistic analysis. Research Papers in Education, 25(2), 137-154. https://doi.org/10.1080/02671520802524810.

Rabe-Hesketh, S., \& Skrondal, A. (2012). Multilevel and longitudinal modeling using stata, Volumes I and II, Third Edition (3rd ed.). Stata Press.

Reichert, F. (2017). Young adults' conceptions of 'good' citizenship behaviours: A latent class analysis. Journal of Civil Society, 13(1), 90-110. https://doi.org/10.1080/17448689.2016.127 0959.

Reichert, F., \& Print, M. (2018). Civic participation of high school students: The effect of civic learning in school. Educational Review, 70(3). https://doi.org/10.1080/00131911.2017.1316239.

Reimers, F. M., Ortega, M. E., Cardenas, M., Estrada, A., \& Garza, E. (2014). Empowering teaching for participatory citizenship: Evaluating the impact of alternative civic education pedagogies on civic attitudes, knowledge and skills of eighth-grade students in Mexico. JSSE-Journal of Social Science Education, 13(4), 41-55.

Rights, J. D., Preacher, K. J., \& Cole, D. A. (2019). The danger of conflating level-specific effects of control variables when primary interest lies in level-2 effects. British Journal of Mathematical and Statistical Psychology, 4, bmsp.12194. https://doi.org/10.1111/bmsp.12194.

Sampermans, D., Isac, M. M., \& Claes, E. (2018). Can schools engage students? Multiple perspectives, multidimensional school climate research in England and Ireland. Journal of Social Science Education, 17(1), 13-28. https://doi.org/10.4119/UNIBI/jsse-v17-i1-1675.

Schlozman, K. L., Verba, S., \& Brady, H. E. (2012). The unheavenly chorus: Unequal political voice and the broken promise of American democracy. Princeton University Press.

Schulz, W., Ainley, J., Fraillon, J., Kerr, D., \& Losito, B. (2010). ICCS 2009 international report: Civic knowledge, attitudes, and engagement among lower-secondary school students in 38 countries. Amsterdam, the Netherlands: International Association for the Evaluation of Educational Achievement (IEA).

Schulz, W., Ainley, J., Fraillon, J., Losito, B., Agrusti, G., \& Friedman, T. (2018a). ICCS 2016 international report: Becoming citizens in a changing world. Springer.

Schulz, W., Carstens, R., Losito, B., \& Fraillon, J. (Eds.). (2018b). ICCS 2016 technical report. Amsterdam, the Netherlands: International Association for the Evaluation of Educational Achievement (IEA).

Sigel, R. (1965). Assumptions about the learning of political values. The ANNALS of the American Academy of Political and Social Science, 361(1), 1-9. https://doi.org/10.1177/000271626536 100101.

Stapleton, L. M. (2013). Incorporating sampling weights into single- and multilevel analyses. In L. Rutkowski, M. von Davier, \& D. Rutkowski (Eds.), Handbook of international large scale assessment: background, technical issues, and methods of data analysis (pp. 363-388). Chapman and Hall/CRC. 
Stapleton, L. M., Yang, J. S., \& Hancock, G. R. (2016). Construct meaning in multilevel settings. Journal of Educational and Behavioral Statistics, 41(5), 481-520. https://doi.org/10.3102/107 6998616646200.

Thapa, A., Cohen, J., Guffey, S., \& Higgins-D'Alessandro, A. (2013). A review of school climate research. Review of Educational Research, 83(3), 357-385. https://doi.org/10.3102/003465431 3483907.

Treviño, E., Béjares, C., Wyman, I., \& Villalobos, C. (2018). Influence of teacher, student and school characteristics on students' attitudes toward diversity. In A. Sandoval-Hernández, M. M. Isac, \& D. Miranda (Eds.), Teaching tolerance in a globalized world (pp. 33-65). IEA Research for Education series. Cham, Switzerland: Springer. https://doi.org/10.1007/978-3-319-78692-6_4.

Treviño, E., Villalobos, C., Béjares, C., \& Naranjo, E. (2019). Forms of youth political participation and educational system: The role of the school for 8th grade students in Chile. Young, 27(3), 279-303. https://doi.org/10.1177/1103308818787691.

van Deth, J. W. (2017). Compliance, trust and norms of citizenship. In S. Zmerli \& T. van der Meer (Eds.), Handbook on political trust (pp. 212-227). Edward Elgar Publishing Limited.

Verba, S., Burns, N., \& Schlozman, K. L. (2003). Unequal at the starting line: Creating participatory inequalities across generations and among groups. The American Sociologist, 34(1-2), 45-69. https://doi.org/10.1007/s12108-003-1005-y.

Verba, S., Schlozman, K. L., \& Brady, H. E. (1995). Voice and equality: Civic voluntarism in American politics. Harvard University Press.

Vermunt, J. K. (2003). Multilevel latent class models. Sociological Methodology, 33(1), 213-239. https://doi.org/10.1111/j.0081-1750.2003.t01-1-00131.x.

Weinberg, J., \& Flinders, M. (2018). Learning for democracy: The politics and practice of citizenship education. British Educational Research Journal, 44(4), 573-592. https://doi.org/10.1002/berj. 3446.

Westheimer, J., \& Kahne, J. (2004a). Educating the "good" citizen: Political choices and pedagogical goals. Political Science and Politics, 37(02), 241-247. https://doi.org/10.1017/S10490965040 04160.

Westheimer, J., \& Kahne, J. (2004b). What kind of citizen? The politics of educating for democracy. American Educational Research Journal, 41(2), 237-269. https://doi.org/10.3102/000283120410 02237.

Wilkenfeld, B. (2009). Does context matter? How the family, peer, school, and neighborhood contexts relate to adolescents' civic engagement. The Center for Information \& Research on Civic Learning \& Engagement, CIRCLE. https://files.eric.ed.gov/fulltext/ED507176.pdf.

Willms, J. D. (2010). School composition and contextual effects on student outcomes. Teachers College Record, 112(4), 1008-1037.

Ernesto Treviño is Associate Professor at the School of Education at Pontificia Universidad Católica de Chile. He is Principal Investigator at the Center for Educational Justice, and director at Centro para la Transformación Educativa (CENTRE UC). He holds a Doctorate in Education from Harvard University, US. His research interest includes education inequalities, public policy in education, and citizenship education.

Diego Carrasco is a Researcher at Centro de Medición MIDE UC, at Pontificia Universidad Católica de Chile. He holds a Doctoral degree in Psychology and a Master of Research in Psychological Methods from the University of Sussex. His research work focuses on contextual effects specification, learning environment research, and its substantive applications to civic education.

Natalia López Hornickel is a Research Assistant at Pontificia Universidad Católica de Chile (PUC). She holds a master's degree in Sociology, and she is Sociologist from PUC. Her research work includes civic and citizenship education, gender equality, work trajectories, and social 
research methodologies. Currently, she is investigating citizenship attitudes with a gender perspective using large-scale assessment data.

Carmen Gloria Zúñiga is an Assistant Professor at the Faculty of Education of the Pontifical Catholic University of Chile. She holds a Doctoral degree in Education from the University of Western Australia. Her research work focuses on teaching and learning of history and social sciences, citizenship education, and classroom assessment.

Open Access This chapter is licensed under the terms of the Creative Commons AttributionNonCommercial 4.0 International License (http://creativecommons.org/licenses/by-nc/4.0/), which permits any noncommercial use, sharing, adaptation, distribution and reproduction in any medium or format, as long as you give appropriate credit to the original author(s) and the source, provide a link to the Creative Commons license and indicate if changes were made.

The images or other third party material in this chapter are included in the chapter's Creative Commons license, unless indicated otherwise in a credit line to the material. If material is not included in the chapter's Creative Commons license and your intended use is not permitted by statutory regulation or exceeds the permitted use, you will need to obtain permission directly from the copyright holder.

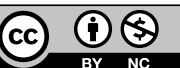

